\title{
The effects of Methenolone Enanthate Supplement with Exercise on Rats' bones
}

\author{
Mehmet ÖZDEMİ, Sefa LÖK
}

Selcuk Universty, Faculty of Sport Science, Konya, Turkey

Address Correspondence to S, Lök, e-mail: sefalok@selcuk.edu.tr

\begin{abstract}
It is known that anabolic steroids are used by athletes to increase their performance and cause many health problems. This study aims to analyze the effects of methenolone enanthate supplement with exercise on rats' bones. The study was conducted with 28 28-day-old Wistar male rats obtained from the Chair of the Experimental Medicine Research and Application Center of Selcuk University. The rats were allocated into four groups: C (control, n:6), E (exercise, n:7), M (methenolone enanthate, n:7) and ME (methenolone enanthate+exercise, $\mathrm{n}: 8$ ). The required doses were arranged weekly depending on the rats' live weight for the groups given methenolone enanthate. The rats' front and back extremity bones were dissected, and the humerus and femur bones were dried. Each bone's length, corpus thickness, cortex thickness and medullary diameter points were determined. The results were presented as mean \pm SD. ANOVA and Duncan's test were used for inter-group comparison of the data. The threshold for statistical significance was $\mathrm{p}<0.05$. The femur length was $32.46 \pm 0.29$ in the $C$ group, $32.60 \pm 0.64$ in the $E$ group, $31.37 \pm 0.50$ in the ME group and 31.67 \pm 0.52 in the $M$ group. The humerus length was $26.42 \pm 0.28$ in the $C$ group, $26.23 \pm 0.59$ in the E group, $25.31 \pm 0.40$ in the ME group and $25.35 \pm 0.45$ in the $\mathrm{M}$ group. The femur and humerus length was statistically significantly shorter in the groups that received methenolone enanthate supplement ( $\mathrm{M}$ and ME) than that of the other two groups $(\mathrm{p}<0.05)$. No statistically significant difference was found between the $\mathrm{C}, \mathrm{E}, \mathrm{M}$ and $\mathrm{ME}$ groups in terms of the cortex and corpus thickness and medullary diameter of their femur and humerus bones ( $p>0.05$ ). It was concluded based on the study results that methenolone enanthate supplement causes early epiphyseal closure in rats' femur and humerus bones and stops the increase in these bones' length. In addition, exercise was found not to reduce this negative effect of methenolone enanthate. Although the prohibited substances classified as anabolics are considered to increase performance by some athletes, these substances are not recommended for use due to their negative effects on athletes' health.
\end{abstract}

Keywords: anabolic steroids, methenolone enanthate, rats, femur, humerus

\section{INTRODUCTION}

Anabolic androgenic steroids (AAS) are synthetic derivatives of testosterone. These substances bind similar to the anabolic and androgenic effects of testosterone produced in the body by binding to the androgen receptor in the cells of the tissues to which it will act $(15,23,28)$. AASs are often used to increase muscle strength and size $(3,5,10,13,30)$. AASs show similar effects to the effects of testosterone or dihydrotestosterone in the body, increasing the protein synthesis in cells and helping the development of tissues (9). Anabolic agents that increase muscle mass and muscle strength lead to an increase in endurance, reduce body fat, it is reported that performs faster recovery time after exercise $(11,14,16)$.

These substances; bodybuilders to have less fat mass, weightlifters to lift more weight, Athletics provides the hammer, shot, throw away more appliances such as javelin, swimmers are using in order to withstand long-term, and competition in the high density. In addition, these substances are commonly used to correct physical appearance among young people and adults $(5,13,24)$.

The strength, stamina and speed used by athletes to increase anabolic agents, cardiovascular system cardiomyopathy $(4,5,22)$ and sudden heart attack (17), cerebrovascular diseases in the brain and nervous system (1), impaired immune function in the liver, early use of the epiphyses in the bones with the use of young age $(17,21,33)$ impaired immune function in the liver, early use of the epiphyses in the bones with the use of young age (2, $8)$.

The aim of this study is; to examine the effects of exercise supplementation with methenolone enanthate on some bones of rats. 


\section{MATERIAL AND METHOD}

The study was carried out on 28 rats (Wistar, Male), 28 days old from Selcuk University Experimental Medicine Research and Application Center. Rats were divided into 4 equal groups: Control (C), Exercise (E), Methenolone enanthate (M), Methenolone enanthate + Exercise (ME). The trial period lasted a total of 5 weeks. The availability of rat, care, feeding and experimental practice was held at Selcuk University Experimental Medicine Research and Application Center. The rats in the experimental animal units, plastic rat cages at $23 \pm 2$

- $\mathrm{C}$ room temperature, $50 \pm 10 \%$ relative humidity environment at, 12/12 night / day in photoperiod were housed fed my adlibit. The rats were provided with daily fresh water $(\sim 50 \mathrm{ml} /$ day / rat $)$ that they could drink at any time. The study was approved by the Ethics Committee of the Center for Experimental Medicine in Selcuk University (number of decisions: 2017-9). The rats were grouped as follows.

Group 1, (Control group, n: 6): Standard rat feeding and drinking water ad libitum were given during the study period.

Group 2, (Exercise group, n: 7): Standard rat feed and drinking water were given adlibitum during the study period. This group of rats during work 5 days a week, was floated 40 min per day.

Group 3, M (Metenolon enantat, n:7): During the study it was given standard rat chow and drinking water as I adlibit. Methenolone enanthate (Rimobolan ampoule 100mg / 1ml) was administered at $10 \mathrm{mg} / \mathrm{kg} /$ rat dose (20) in $100 \mathrm{mcl}$ castor oil and was administered intramuscularly for 5 days for 5 weeks.

Group 4, ME (Metenolon Enantat + Exercise group, n:8): During the study, standard rat feed and drinking water were given as ad libitum. Metabolic enanthate (Rimobolan ampoule $100 \mathrm{mg} / 1 \mathrm{ml}$ ) was administered to this group at a dose of $10 \mathrm{mg} / \mathrm{kg}$ daily for 5 days. It was then incorporated into exercise programs.

Exercise Program: The rats in the swimming exercise group were given swimming training in the swimming tank for 5 weeks, 5 days a week for 40 min. The water tank temperature will be filled with 25 oC water for 1 hour and the water hot water temperature will be 22-25 oC. At the beginning of the exercise, the rats were kept free in the water for 15 minutes to adapt to the water and then the swimming exercise program was applied.

Measurements: At the end of the study, the anterior and posterior extremities of the subjects were dissected and dissected and the required length, corpus thickness, cortex-cortical bone thickness and medullary diameter-cavum medullare measurements were performed for each of the revealed humerus and femur bones with a $0-100 \mathrm{~mm}$ caliper.

Statistical Analysis: SPSS 18.0 (SPSS 18.0 for Windows / SPSS® Inc, Chicago, USA) package program was used for statistical evaluation of the data. The results were presented as mean \pm SD. ANOVA and Duncan test were used to compare data between groups $(p<0,05)$.

\section{RESULTS}

Table 1. Comparison of length and thickness of corpus, cortex and medullar diameters of femur bones. (Mean \pm SD)

\begin{tabular}{lcccc}
\hline Groups & Height & Cortex & Corpus & Medullar \\
\hline $\mathbf{M}$ & $31.67 \pm 0.52^{\mathrm{a}}$ & $0.51 \pm 0.03^{\mathrm{a}}$ & $2.45 \pm 0.12^{\mathrm{a}}$ & $1.58 \pm 0.93^{\mathrm{a}}$ \\
\hline $\mathbf{M E}$ & $31.37 \pm 0.50^{\mathrm{a}}$ & $0.49 \pm 0.02^{\mathrm{a}}$ & $2.44 \pm 0.63^{\mathrm{a}}$ & $1.56 \pm 0.17 \mathrm{a}$ \\
\hline $\mathbf{E}$ & $32.60 \pm 0.64^{\mathrm{b}}$ & $0.52 \pm 0.07^{\mathrm{a}}$ & $2.51 \pm 0.34^{\mathrm{a}}$ & $1.67 \pm 0.19 \mathrm{a}$ \\
\hline $\mathbf{C}$ & $32.46 \pm 0.29^{\mathrm{b}}$ & $0.49 \pm 0.02^{\mathrm{a}}$ & $2.37 \pm 0.03^{\mathrm{a}}$ & $1.51 \pm 0.32^{\mathrm{a}}$ \\
\hline Test value, $\mathbf{p}$ & $\mathrm{F}=9.701 \mathrm{p}=0.000^{*}$ & $\mathrm{~F}=6.476 \mathrm{p}=0.40$ & $\mathrm{~F}=0.456 \mathrm{p}=0.47$ & $\mathrm{~F}=0.014 \mathrm{p}=0.25$
\end{tabular}

Different letters in the same column $(a, b)$ are statistically significant (Duncan test, $p<0.05)$.

In Table 1 , the distribution of femoral height, cortex, corpus and medullar diameter mean of $\mathrm{M}, \mathrm{ME}, \mathrm{E}$ and $\mathrm{C}$ rats were investigated. When the intergroup femur height were compared, it was $31.67 \pm 0.52$ for $M$ group, $31.37 \pm 0.50$ for $\mathrm{ME}$ group, $32.60 \pm 0.64$ for group $\mathrm{E}$, and $32.46 \pm 0.29$ for group
C. There was a statistically significant difference between the mean of intergroup femur height. To determine which group the difference was caused by the Duncan post hoc test, it was found that the difference was caused by $\mathrm{ME}$ and $\mathrm{M}$ groups $(\mathrm{F}=$ 9.701, $\mathrm{p}=0.000)$ 
The mean femoral bone cortex thickness of the group $\mathrm{M}$ rats was $0.51 \pm 0.03$, the mean femoral bone cortex thickness of the ME group was $0.49 \pm 0.02$, the mean femoral bone cortex thickness of the group $\mathrm{E}$ rats was $0.52 \pm 0.07$ and the mean femoral bone cortex thickness of the $C$ group was $0.49 \pm 0.02$. M, $\mathrm{ME}, \mathrm{E}$ and $\mathrm{C}$ groups were not statistically significant difference between femur cortex thickness averages $(\mathrm{p}>0,05)$.

Femoral bone corpus thickness of femur bone in group $\mathrm{M}$ was $2.45 \pm 0.12$, femoral bone corpus thickness mean of ME 2.44 \pm 0.63 , femoral bone corpus thickness of E group was $2.51 \pm 0.34$ and $\mathrm{C}$ group femoral bone corpus thickness was calculated as $2.37 \pm 0.03$. The difference between femoral corpus averages of $\mathrm{M}, \mathrm{ME}, \mathrm{E}$ and $\mathrm{C}$ groups were not statistically significant ( $p>0.05)$.

The mean femoral bone medullar diameter of the rats in group $\mathrm{M}$ group was $1.58 \pm 0.93$, the medullar diameter of femoral bone was $1.56 \pm 0.17$ in the ME group, the medullar diameter of femural bone in group E group was $1.67 \pm 0.19$ and the $\mathrm{C}$ group mean femoral bone medullar diameter of the rats was calculated as $1.51 \pm 0.32$. M, ME, E and C groups were not statistically significant difference between the mean femur medullar diameter $(\mathrm{p}>0.05)$.

Table 2. Comparison of length and thickness of corpus, cortex and medullar diameters of humerus bones (Mean \pm SD)

\begin{tabular}{lcccc}
\hline Groups & Height & Cortex & Corpus & Medullar \\
\hline $\mathbf{M}$ & $25.35 \pm 0.45^{\mathrm{a}}$ & $0.42 \pm 0.07^{\mathrm{a}}$ & $2.11 \pm 0.75^{\mathrm{a}}$ & $1.24 \pm 0.24^{\mathrm{a}}$ \\
\hline $\mathbf{M E}$ & $25.31 \pm 0.40^{\mathrm{a}}$ & $0.43 \pm 0.06^{\mathrm{a}}$ & $2.20 \pm 0.68^{\mathrm{a}}$ & $1.25 \pm 0.24^{\mathrm{a}}$ \\
\hline $\mathbf{E}$ & $26.23 \pm 0.59^{\mathrm{b}}$ & $0.47 \pm 0.04^{\mathrm{a}}$ & $2.23 \pm 0.07^{\mathrm{a}}$ & $1.27 \pm 0.33^{\mathrm{a}}$ \\
\hline $\mathbf{C}$ & $26.42 \pm 0.28^{\mathrm{b}}$ & $0.46 \pm 0.01^{\mathrm{a}}$ & $2.22 \pm 0.42^{\mathrm{a}}$ & $1.30 \pm 0.51^{\mathrm{a}}$ \\
\hline Test value, $\mathbf{p}$ & $\mathrm{F}=11.398 \mathrm{p}=0.000^{*}$ & $\mathrm{~F}=4.601 \mathrm{p}=0.24$ & $\mathrm{~F}=3.024 \mathrm{p}=0.63$ & $\mathrm{~F}=6.024 \mathrm{p}=0.17$ \\
\hline
\end{tabular}

Different letters in the same column $(a, b)$ are statistically significant (Duncan test, $p<0.05)$.

In Table 2, distribution of humerus height, cortex, corpus and medullar diameter mean of $\mathrm{M}$, $\mathrm{ME}, \mathrm{E}$ and $\mathrm{C}$ rats were examined. The mean height of the intergroup humerus was $25.35 \pm 0.45$ for $\mathrm{M}$ group, $25.31 \pm 0.40$ for ME group, $26.23 \pm 0.59$ for group $\mathrm{E}$, and $26.42 \pm 0.28$ for group $\mathrm{C}$. There was a statistically significant difference between the mean of intergroup humerus height. It was found that the difference was caused by ME and M groups in the Duncan post hoc test to determine which group the difference was caused. ( $F=11.398, p=0.000)$.

The mean thickness of the humeral bone cortex of group $\mathrm{M}$ rats was $0.42 \pm 0.07$, the mean humeral bone cortex thickness of the ME group was $0.43 \pm$ 0.06 , the mean humeral bone cortex thickness of the group $\mathrm{E}$ rats was $0.47 \pm 0.04$ and $\mathrm{C}$ group The mean humeral bone cortex thickness of the rats was $0.46 \pm$ 0.01. M, ME, E and C groups were not statistically significant difference between the mean thickness of humerus cortex. ( $p>0.05)$.

The mean thickness of the humeral bone corpus in group $M$ group was $2.11 \pm 0.75$, the mean of humeral bone corpus thickness ME group was $2.20 \pm$ 0.68 , the mean humeral bone corpus thickness $\mathrm{E}$ group was $2.23 \pm 0.07$ and the mean humeral bone corpus thickness of the rats was calculated $C$ group was $2.22 \pm 0.42$. M, ME, E and $\mathrm{C}$ groups were not statistically significant difference between humerus cortex thickness averages ( $p>0.05)$.

The mean thickness of the humeral bone medullar diameter in group $\mathrm{M}$ group was $1.24 \pm 0.24$, the mean of humeral bone medullar diameter $\mathrm{ME}$ group was $1.25 \pm 0.24$, the mean humeral bone medullar diameter E group was $1.27 \pm 0.33$ and the mean humeral bone medullar diameter of the rats was calculated C group was $1.30 \pm 0.51$. M, ME, E and $\mathrm{C}$ groups were not statistically significant difference between humerus medullar diameter averages $(\mathrm{p}>0.05)$.

\section{DISCUSSION}

Bonnet et al. (7) beta 2 agonists in the study on the effect of bones of female rats, femoral bone length in females in the group given a shorter length of drug administration.

Xiaodong et al. (32) in rats in the study of the effects of nandrolone on bone mass and metabolism in their study; They reported that the humerus bone of the rats given was shorter than the control group. Prakasam et al. (25) examined the effect of testosterone on the development of cortical bone and bone in rats. They reported that femur length lengths of testosterone treated rats were short.

Kilc1 and Lok (18) swimming exercise of testosterone supplementation applied in a study in 
male rats examined effects on bone morphometry; reported that early growth of the femur and humerus bones of male rats resulted in an early closure of their length.

Tasgin et al. (29) in women who regularly swimming testosterone supplementation on the humerus and femoral bone morphometric effects of the study examined the humerus and femur bones of the groups in testosterone supplemented rats in the groups reported that they are shorter than the other groups.

Beck et al. (6) testosterone in their study examined the effect of femoral bone; Testosterone applied to the experimental group of femur bones were shorter than stated.

In addition, it was reported that anabolic androgenic steroid administration did not make a significant difference in the corpus thickness (12), cortex thickness (31) and medullar diameters $(19,26$, 27).

\section{CONCLUSIONS}

The study revealed that methenone enanthate supplementation could stop the growth of these bones by causing early epiphyseal closure in femur and humerus bones of untreated young rats.

As a result; It is thought that athletes and sedentary individuals using anabolic steroids especially at a young age may cause negative effects on bone development.

\section{ACKNOWLEDGEMENTS}

This study is a portion of master thesis and is supported by Selcuk University Scientific Research Projects Coordinator (SUBAPK, 17202006).

1. Aggarwal T, Polanco MJ, Scaramuzzino C, Rocchi A, Milioto C, Emionite L, Ognio E, Sambataro F, Galbiati M, Poletti A, Pennuto M, 2014. Androgens affect muscle, motor neuron, and survival in a mouse model of SOD1-related amyotrophic lateral sclerosis. Neurobiology of Aging, 1-10.

2. Amer HE, Asker SA, Mazroa SA, 2011. Structural changes and immunohistochemical localisation of edidermal growth factor receptor in the true vocal fold of female albino rats administered anabolic adrogenic steroids, and effects of antiandrogen therapy. The Journal of Laryngology \& Otology, 125, 829-36.

3. Amsterdam JV, Opperhuizen A, Hartgens F, 2010. Adverse health effects of anabolic-androgenic steroids. Regulatory Toxicology and Pharmacology, 57, 117-23.

4. Baggish AL, Weiner RB, Kanayama G, Hudson JI, Picard MH, Hutter AM, Pope HG, 2010. Long-term anabolic-androgenic steroid use is associated with left ventricular dysfunction. Circ Heart Fail, 3, 472-76.

5. Barkhe MS, Yesalis CE, 2004. Abuse of anabolic androgenic steroids and related substances in sport and exercise. Current Opinion in Pharmacology, 4, 614-20.
6. Beck DT, Yarrow JF, Beggs LA, Otzel DM, Ye F, Conover CF Williams AA, 2014. Influence of Aromatase Inhibition on the Bone-Protective Effects of Testosterone. Journal of Bone and Mineral Research, 29(11), 2405-13.

7. Bonnet N, Benhamou CL, Brunet-Imbault B, Arlettaz A, Horcajada MN, Richard O, Vico L, Collomp K, Courteix D, 2005. Severe bone alterations under $\beta 2$ agonist teratments: Bone mass, microarchitecture and strength analyses in female rats. Bone, 37, 622-33.

8. Borges T, Eisele G, Byrd C, 2001. Rewiev of androgenic anabolic steroid use. Office of Safeguards and Security U.S. Department of Energy, 1-18.

9. Chin K Y, Ima-Nirwana S. 2017 The Effects of Testosterone Deficiency and Its Replacement on Inflammatory Markers in Rats: A Pilot Study. International Journal of Endocrinology and Metabolism, (Inpress). 12,125- 136.

10. Chung KJ, Kim KH, 2015. Forbidden fruit for athletes, but possible divine blessing for rehabilitation: testosterone. Journal of Exercise Rehabilitation, 11(1), 2-4.

11. Fontana K Campos GER, Staron RS, Cruz-Höfling MA, 2013. Effects of Anabolik Steroids and High-Intensity Aerobic Exercise on Skeletal Muscle of Transgenic Mice. PLoS One, 8(11), 1-8.

12. Gunness M, Orwoll E, 1995. Early induction of alterations in cancellous and cortical bone histology after orchiectomy in mature rats. Journal of Bone and Mineral Research, 10, 173544.

13. Harmer PA, 2010. Anabolic-androgenic steroid use among young male and female athletes: is the game to blame. Br J Sports Med, 44, 26-31.

14. Hoffman JR, Ratamess NA, 2006. Medical issues associated with anabolic steroid use: are they exaggerated. Journal of Sports Science and Medicine, 5, 183-93.

15. Kassem HH, Dashti R, Jarallah M, 2014. Anabolic Steroids and Testosterone Abuse; a Possible Cause of Myocardial Infarction in Young Age, 20, 2685-87.

16. Kerr JM, Congeni JA, 2007. Anabolic-androgenic steroids: use and abuse in pediatric patients. Pediatr Clin N Am, 54, 777185 .

17. Kicman AT, 2008. Pharmacology of anabolic steroids.British Journal of Pharmacology, 154, 502-21.

18. Kılc1 A, Lok S. Morphometric Effects Of Testosterone Supplementation On Certain Extremity Bones In Young Swim-Trained Rats. Turkish Journal of Sport and Exercise, 2018; 20(3), 140-144.

19. Kim B, Mosekilde L, Duan Y, Zhang XZ, Tornvig L, Thomsen JS, Seeman E, 2003. The structural and hormonal basis of sex differences in peak appendicular bone strength in rats. J Bone Miner Res, 18:150-5.

20. Lok S, 2015. Does the use of Testosterone Enanthate as a Form of Doping in Sports Cause Early Closure of Epiphyseal in Bones?". International journal of morphology, 33(4), pp. 12014.

21. Lok S, Yalcin H, 2010. Morphometric effect of nandrolone decanoate used as doping in sport on femur of rats in puberty period. Archives of budo, 6(4), 1771-5.

22. Maravelias C, Dona A, Stefanidou M, Spiliopoulou C, 2005. Adverse effects of anabolic steroids in athletes: A constant threat. Toxicol Lett, 158, 167-75.

23. Momaya A, Fawal M, Estes R, 2015. Performance-Enhancing Substances in Sports: A Review of the Literature. Sports Med, $45,517-31$

24. Papazisis G, Kouvelas D, Mastrogianni A, Karastergiou A, 2007. Anabolic androgenic steroid abuse and mood disorder. A case report Int J Neuropsychopharmacol, 10(2), 292-293. 
25. Prakasam G, Yeh JK, Chen MM, Magana MC, Liang CT, Aloia JF, 1999. Effects of growth hormone and testosterone on cortical bone formation and bone density in aged orchiectomized rats. Bone, 5, 491-7.

26. Qu Q, Heapei MP, Kapanen, JA, Salo DJ , Väänänen HK, Härkönen P. Estrogen enhances differentiation of osteoblasts in mouse bone marrow culture. Bone. 1998;22: 201-9.

27. Sims NA, Dupont S, Krust A, Clement-Lacroix P, Minet D, Resche-Rigon M, Gaillard-Kelly M, Baron R, 2002. Deletion of estrogen receptors reveals a regulatory role for estrogen receptors in bone remodeling in females but not in males. Bone, 30, 18-25.

28. Solbach P,Potthoff A, Raatschen HJ, Soudah B, Lehmann U, Schneider A, Gebel MJ, Manns MP, Vogel A, 2015. Testosterone-receptor positive hepatocellular carcinoma in a 29-year old bodybuilder with a history of anabolic androgenic steroid abuse: a case report. BMC Gastroenterology, 15, 60.

29. Tasgin E, Akkus H, Lok S, 2016. Morphometric Effects of Testosterone İntake On Bones of Femur and Humerus İn Female Rats Which Regularly Swim. 14th International Sport Sciences Congress, Book of Abstracts, p 458, 01st-04th November, Belek-Antalya

30. Thevis M, Schanzer W, 2007. Mass spectrometryin sports drug testing: structure characterization and alalytical assays. Mass Spectrometry Reviews, 26, 79-107.

31. Weisman Y, Cassorla F, Malozowski S, Krieg R J, Goldray D, Kaye A M, Somjen D, 1993. Sex-specific response of bone cells to gonadal steroids: modulation in perinatally androgenized females and in testicular feminized male rats. Steroids. 58: 126-33.

32. Xiaodong L, Takahashi M, Kushida K, Shimizu S, Hoshino H, 2000. The effect of nandrolone decanoate on bone mass and metabolism overectomized rats with ostepeni. J Bone Miner Metab, 18, 258-63.

33. Yavari A, 2009. Abuse of anabolic androgenic steroids. Journal of Stress Physiology \& Biochemistry, 5(3), 22-32. 